International Journal of Engineering \& Technology, $7(4.38)(2018) 852-855$
International Journal of Engineering \& Technology
SPC
Website: www.sciencepubco.com/index.php/IJET
Research paper

\title{
LTV, Macro Economics and ROE to Stock Return in Real Estate and Property Companies Listed on LQ 45 Period 2009 - 2017
}

\author{
Riko Hendrawan', Avi Avitianti \\ ${ }^{1}$ Telkom University \\ Bandung, Indonesia \\ riko_hendrawan@yahoo.com \\ ${ }^{2}$ Telkom University \\ Bandung, Indonesia
}

\begin{abstract}
The purpose of this research is to exemine the effect of Loan to Value (LTV), exchange rate, Gross Domestic Product (GDP), Interest Rate and Return on Equity (ROE) to return of property stock that entered at LQ 45 in Indonesia Stock Exchange period 2009 - 2017. Using selected 5 Real Estate and Property Companies as research samples. Panel Data Regression Tehniques were use for this research. The result of this research is LTV partially has no significant effect on stock return, partial exchange rate has no significant effect on stock return, GDP partially significant effect of stock return interest rate partially does not have significant influence retun share, ROE partially significant effect of stock return and there is simultaneously significant influence between LTV, exchange rate, GDP, interest rate and ROE to stock return.
\end{abstract}

Keywords: GDP, LTV,ROE,Stock Return

\section{Introduction}

March 2012, Bank Indonesia (BI) began tightening its Loan to Value (LTV) policy through Bank Indonesia Circular Letter No.14 / 10 / DPNP concerning Risk Management Implementation of Banks conducting the provision of Home Ownership Credit and Motor Vehicle Credit issued on March 15, 2012. The adoption of the LTV Policy directly affected the property industry, a decline in property sales as released by the Primary Market Residential Property Price Survey conducted by the Rill Sector Statistics Division, Statistics Department of Bank Indonesia is illustrated in Graph 1.1

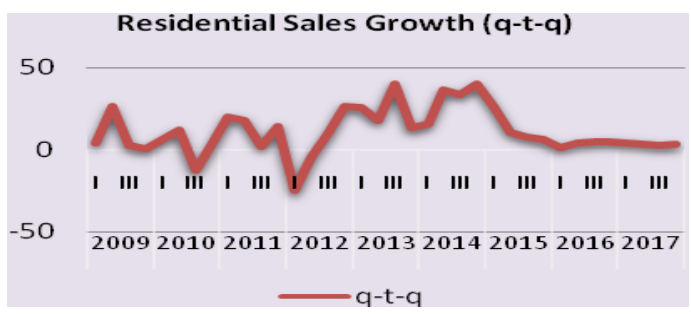

Graph 1.1: Residential Sales Growth

In Graph 1.1, the sales volume of residential in quarter IV-2013 is slowed. Survey results show that quarterly residential property sales is slowing down from $39.80 \%$ (qtq) to $13.05 \%$ (qtq). The existence of the 2013 provision of LTV policy also has an impact on the decrease in occupancy demand. The slowing increase in sales mainly occurs in small type houses. Quoted from the Prima- ry Market Residential Property Price Survey (IHPR), the decline in property sales volume triggered a decline in property prices. According to (Ang, 1997), there are factors that affect the return of an investment. First, internal factors such as the quality and reputation of management, capital structure, corporate debt structure, and so forth. The second concerns external factors, such as the influence of monetary and fiscal policy, the development of the industrial sector, economic factors such as changes in exchange rates, prevailing interest rates, changes in GDP (Gross Domestic Product), and so forth. LTV policy is also one of the macroeconomic variables that can affect stock returns.

The effects of LTV, exchange rate, GDP, interest rate and ROE on stock returns have been studied by (Suharyanto \& Asma, 2013) and (Setiawan \& Mimba, 2015) examined the abnormal return stock analysis before and after LTV regulations. (Nasution, 2013) examines the effect of LTV and macroeconomic variable shock on the growth of the property industry. Then (Nasir \& Mirza, 2011), (Aquasari, 2011), (Pratiwi \& Hendrawan, 2014), (Lukisto \& Anastasia, 2014), examine the macro economic effects such as exchange rate, GDP and interest rate on stock return. (Anwar \& Farida, 2016), (Salim \& Simatupang, 2016), (Maulida, Utami, \& Sumani, 2010), (Sudarno \& Pratiwi, 2014) and (Hadiansyah \& Gunawan, 2017) in addition to researching macroeconomic influences also examine the performance of companies represented by ROE , ROA and other company ratios.

\section{Literature review}

(Hadiansyah \& Gunawan, 2017) evaluated Macroeconomic and Fundamental Analysis of Banking Share Price Listed on LQ 45 Index. With partial results Inflation has no effect and positive on 
banking stock prices. The exchange rate of currency, ROA and DER have an effect and negative to banking stock price. ROE and LDR have no effect and negative to banking stock price. EPS has a positive and positive effect on banking stock prices. Simultaneously variable of inflation, currency exchange rate, ROA, ROE, EPS, DER, and LDR influence to stock price of banking.

(Salim \& Simatupang, 2016) evaluates the Financial Performance and Macroeconomic Conditions against Stock Returns of Property and Real Estate Companies Listed on Indonesia Stock Exchange for the Period of 2011-2014. With DER result have negative and insignificant effect to stock return, ROA have no significant effect on stock return, TATO and PER have positive and significant effect to stock return, inflation and exchange rate have no significant negative effect to stock return. Financial performance variable and macroeconomic condition simultaneously have a significant effect on stock return.

Systematic Risk, Internal and External Factors of Companies on Stock Return is the title studied (Anwar \& Farida, 2016), with the results of systematic risk research $(\beta)$, ROE, positively affect the stock return, DER, ROA and Interest Rate does not affect the stock return while inflation and the exchange rate has a negative effect on stock return

(Setiawan \& Mimba, 2015) evaluated the Market Reaction to Loan to Value, using event study with significant market reaction to the announcement, namely $\mathrm{t}-1$ day (one day before announcement), $\mathrm{t}-0$ (at the time of announcement) and $\mathrm{t}+2$ (two days after the announcement). There is no difference in market reaction before and after the announcement of loan to value regulation with a 7-day event period

Research of (Lukisto \& Anastasia, 2014) on Macro Economic Impact on Indonesia Property Stock Index in Indonesia period 1994 - 2012, with simultaneous / simultaneous result Inflation, Interest Rates, Exchange Rate and GDP have significant influence to IHSG. Partially, the interest rate has a significant negative effect and the Rupiah Exchange Rate to Dollar has a significant positive effect on Stock Price Index. As for inflation and GDP growth partially does not affect the stock price index good stock price index property sector.

(Pratiwi \& Hendrawan, 2014) Research concerning Influence of Composite Stock Price Index, Macro Economic Factor and Dow Jones Industrial Average Index to LQ 45 Stock Price Index for 2008- 2012 period in Investment Decision, using multiple linear regression analyst technique and simultaneous research result of IHSG, BI Rate, money supply and dow jones index affect LQ 45 stock price index. In partialal only LQ 45 and money supply that influence LQ 45 stock price index.

Influence of Exchange Rate, Inflation, Deposit Interest Rate \& Stock Trading Volume On Stock Return On Banking Companies Listed on Indonesia Stock Exchange is the title examined by (Nasir \& Mirza, 2011). With the results of research exchange rate has no significant effect on stock returns. Inflation, Deposit Interest Rate and Stock Trading Volume have a positive effect on stock return.

(Aquasari, 2011) research on the analysis of macroeconomic factors that affect the stock prices in the Telecommunications industry listed on the Indonesia Stock Exchange. with simultaneous research results/GDP simultaneously, interest rate, inflation and exchange rate have a significant effect on Stock Price. Partially GDP, inflation and exchange rate have no significant effect. As for inflation and interest rate growth partially affect the stock price of both stock price index property sector.

(Maulida et al., 2010) research using path path analysis, examining the Influence of Exchange Rate and SBI Rate and inflation through Return on Asset to Stock Return. With the exchange rate significant negative effect on ROA, Interest rate has a significant positive effect on ROA, Inflation has a positive effect is not significant to ROA, Exchange rate and Inflation have no significant negative effect on Return of Interest Rate has no significant positive effect to Return of Stock, ROA has negative significant against stock return.
(Sudarno \& Pratiwi, 2014) evaluated the Influence Analysis of Earning Per Share, Debt to Equity Ratio, Return on Equity and Total Asset Turn Over on stock return of real estate and property firms listed on BEI in 2011-2014 observation. With the results of research partially only EPS and DER significant effect, while ROE and TATO partially no significant effect on stock return.

Simultaneously EPS, DER, ROE and TATO effect on stock return. (Suharyanto \& Asma, 2013) by using the technique of event study analysis, examining Abnormal Return of Stock Analysis before and after Announcement of Loan to Value mortgage regulation, with results rhere is an average difference in abnormal returns before and after the announcement of the KPR LTV regulation. Abnormal return does not occur at the time of announcement of KPR LTV regulation

The Effect of Loan to Value and Shock of Macroeconomic Variables on the Growth of Indonesian Property Industry is the title examined by (Nasution, 2013), using vector auto regressive analysis technique and macro variable variables research result that is inflation and interest rate influencing consumer who is in the process of repayment of credit housing. As for the demand for new housing loans are affected by LTV policy.

(Suharyanto \& Asma, 2013) examined abnormal return stock analysis before and after LTV regulation with event study analysis method. Then (Setiawan \& Mimba, 2015) examine the market reaction to the implementation of LTV regulation also using event study method. (Nasution, 2013) examines the effect of LTV and macroeconomic variable shock on the growth of the property industry, using the method of auto regressive vector analysis. These studies do not discuss the effect of LTV on stock returns.

(Aquasari, 2011), (Lukisto \& Anastasia, 2014), (Anwar \& Farida, 2016), (Maulida et al., 2010) and (Hadiansyah \& Gunawan, 2017) have conducted research with the conclusion of exchange rate effect on stock return. This shows if the rupiah exchange rate strengthened then the stock return will rise. However, the research of (Nasir \& Mirza, 2011), (Pratiwi \& Hendrawan, 2014) and (Salim \& Simatupang, 2016) concluded that the exchange rate has no effect on stock return

Lukisto \& Anastasia (2014) and Pratiwi (2014) with GDP results not affecting stock prices. But in the study of Aquasari (2011) GDP influential GDP on stock returns. The research on the GDP variable is interesting because it can still be different on the results of the research.

(Nasir \& Mirza, 2011),(Nasution, 2013),(Lukisto \& Anastasia, 2014) and (Maulida et al., 2010) have conducted research with the result of interest rate variable having a positive effect on stock return. Based on some research rate if interest rate rise then will have negative effect to stock return. However research (Pratiwi \& Hendrawan, 2014) and (Anwar \& Farida, 2016) suggests that the variable interest rate does not affect the stock return

(Sudarno \& Pratiwi, 2014) and (Hadiansyah \& Gunawan, 2017) with ROE results do not negatively affect the stock price. But research (Anwar \& Farida, 2016) ROE positive influence on stock return. Research on ROE variable is interesting because it can still be different on the result of research

\section{Findings and discussion}

\subsection{Descriptive Analysis}

Descriptive analysis on each variable, described as follows. The stock return has an average of 8.320115, the maximum is 327.0000 , and the minimum is 81 , with a standard deviation of 32.97821. LTV has an average of 81.98276 , maximum 90.00000 , minimum 70.00000 , with standard deviation of 8.428876. Exchange rate has an average of 9.299129 , the maximum is 9.592673 , and the minimum is 9.059169 , with a standard deviation of 0.170754 . GDP has an average of 14.53272 , the maximum is 14.75218 , and the minimum is 14.09118 , with a standard devia- 
tion of 0.176142 . The interest rate has an average of 6.229540 , the maximum is 8.210000 , and the minimum is 3.830000 , with the standard deviation of 0.982052 . ROE has an average of 4.047586, a maximum of 15.21000 , and a minimum of 7.6, with a standard deviation of 3.083559 .

Table 1: Descriptive Statistics

\begin{tabular}{|l|l|l|l|l|l|l|}
\hline & Return & LTV & LnKurs & LnGDP & $\begin{array}{l}\text { Interest } \\
\text { Rate }\end{array}$ & ROE \\
\hline Mean & 8.32011 & 81.9827 & 9.29912 & 14.5327 & 6.22954 & 4.04758 \\
& 5 & 6 & 9 & 2 & 0 & 6 \\
\hline Medi- & 4.00000 & 85.0000 & 9.26624 & 14.5865 & 6.48000 & 3.63500 \\
an & 0 & 0 & 8 & 6 & 0 & 0 \\
\hline \multirow{2}{*}{ Max } & 327.000 & 90.0000 & 9.59267 & 14.7521 & 8.21000 & 15.2100 \\
& 0 & 0 & 3 & 8 & 0 & 0 \\
\hline \multirow{2}{*}{ Min } & -81 & 70.0000 & 9.05916 & 14.0911 & 3.83000 & -7.6 \\
\hline Std. & 32.9782 & 8.42887 & 0.17075 & 0.17614 & 0.98205 & 3.08355 \\
Dev & 1 & 6 & 4 & 2 & 2 & 9 \\
\hline
\end{tabular}

\subsection{The effect of LTV to stock returns}

Table 2: Multiple Regression Analysis

\begin{tabular}{|l|l|l|l|l|}
\hline Variable & Coefficient & Std. Error & T-Statistic & Prob. \\
\hline C & 1194.041 & 300.9272 & 3.967872 & 0.0001 \\
\hline LTV & -0.211401 & 0.396249 & -0.533506 & 0.5944 \\
\hline LnER & 26.13547 & 20.88362 & 1.251482 & 0.2125 \\
\hline LnGDP & -95.67974 & 22.89297 & -4.179437 & 0.0000 \\
\hline Int. Rate & -4.477992 & 3.260531 & -1.373394 & 0.1715 \\
\hline ROE & 1.718640 & 0.860300 & 1.997721 & 0.0474 \\
\hline
\end{tabular}

For the variable LTV (X1) obtained value of $t$ arithmetic equal to 0.533506 . Because $t$ count $(-0.533506)>\mathrm{t}$ table $(-1,974)$, then $\mathrm{H} 0$ is accepted. Therefore, it can be concluded that LTV (X1) partially has no influence and significant to return (Y). The negative value of LTV regression coefficient of -0.211401 means that any increase of LTV (X1) of one unit will cause a decrease in Return (Y) of 0.211401 .

This indicates that during the period of 2009 - 2017 the LTV policy issued in 2012 followed by policy relaxation in 2013 and 2015 has no significant effect on stock returns. The above results show the company's stock return does not respond to policy directly, good corporate financial performance becomes one of the factors affecting stock return. In this research, the object of research is stock of real estate company and property entered in LQ 45 at BEI, so it can be ascertained that the object studied is company having financial condition, growth prospect and high transaction value Earlier studies that examined the effect of LTV on stock returns do not yet exist. There are previous studies on LTV using event study analysis to determine the abnormal return between the period before and after the announcement of KPR LTV regulation by Suharyanto \& Asama (2013).

\subsection{The effect of exchange rate to stock return}

For the exchange rate variable (X2) obtained t value counted 1.251482. Because $t$ count $(1.251482)<t$ table $(1,974)$, then $\mathrm{H} 0$ is accepted. Therefore, it can be concluded that the exchange rate (X2) partially has no significant effect Return (Y). The exchange rate regression coefficient of positive value of 26.13547 means for each increase of Exchange Rate (X2) for one unit will cause the increase of Return (Y) of 26.13547.

This condition indicates that the exchange rate does not have a significant effect on the return of property stocks, where the strengthening or weakening of the exchange rate will have an impact on the flow of foreign funds, in the case of government regulations of citizens or foreign companies may not own property in Indonesia.

The results of this study do not agree with research conducted by (Nasir \& Mirza, 2011) which concluded that the partial exchange rate has an effect on stock return. However, this study is in line with (Pratiwi \& Hendrawan, 2014), (Salim \& Simatupang, 2016) and (Maulida et al., 2010) that the exchange rate has no effect on stock returns.

\subsection{The effect of GDP to stock return}

For the variable of GDP (X3) obtained t value counted -4.179437. Because t count $(-4.179437)>-t$ table $(-1,974)$, then $\mathrm{H} 0$ is rejected. Therefore, it can be concluded that GDP (X3) partially has a significant influence of return $(\mathrm{Y})$. The negative regression coefficient of GDP of -95.67974 means for every increase of GDP (X3) of one unit will cause the decrease of Return (Y) equal to 95.67974.

The results of this study do not agree with research conducted by (Pratiwi \& Hendrawan, 2014), (Lukisto \& Anastasia, 2014) which concluded that partially GDP has no effect on stock returns.

Differences of research results can be due to factors of periods and objects of research on research that has been done before. In this study the period studied 2009 - 2017 with the object of research return LQ45 shares in real estate and property companies. In this condition, although GDP is rising, investors prefer other investment vehicles rather than in sectors such as property and real estate. In addition, the growth in property sector GDP that is still below other sectors also makes investors prefer other sectors alternatives.

\subsection{The effect of interest rate to stock return}

For the variable interest rate (X4) obtained t value counted 1.373394. Because $t$ count $(-1.373394)<t$ table $(-1,974)$, then H0 is accepted. Therefore, it can be concluded that the interest rate (X4) partially has no significant effect Return (Y). The negative interest rate regression coefficient of - 4,477,992 means for each interest rate increase (X4) for one unit will cause the decrease of return (Y) equal to $4,477,992$.

This study is in accordance with the theory expressed, when interest rates rise then the cost of capital will rise and will reduce the profits earned by the company. This will affect the decrease of dividend so that it can affect the investor to sell its shares and will cause the stock return will decrease. Finally, when interest rates rise, investors tend to move their capital from the capital market to the money market.

The results of this study contradict the research conducted by (Nasir \& Mirza, 2011), (Lukisto \& Anastasia, 2014), (Maulida et al., 2010), which concluded that partially interest rates have an effect on stock returns. But this research is in line with, (Pratiwi \& Hendrawan, 2014) and (Anwar \& Farida, 2016), that interest rates have no effect on stock returns

\subsection{The effect of ROE to stock return}

For variable ROE (X5) obtained t value counted 1.997721. Because $\mathrm{t}$ count $(1.997721)>\mathrm{t}$ table $(1,974)$, then H0 is rejected. Therefore, it can be concluded that ROE (X5) partially has a significant influence Return (Y). The regression coefficient of ROE with positive value of 1.718640 means for every increase of ROE (X5) for one unit will cause the increase of Return (Y) equal to $1,718,640$

This indicates that the company's performance is more efficient in using its own capital to generate profit or net profit. The higher the company's earnings then the investor's view of the company is in good condition. High corporate earnings will cause the returns (dividends) to be distributed will also be high.

This research is in line with (Anwar \& Farida, 2016), that ROE has influence on stock return, however contrary to research of (Hadiansyah \& Gunawan, 2017) and (Sudarno \& Pratiwi, 2014) that ROE partially have no significant effect to stock return 


\subsection{The effect of LTV, exchange rate, GDP, interest rate and ROE simultaneously to stock return}

Test Result F, obtained Prob value. F arithmetic of 0.000023 . Because the value of Prob. F arithmetic $(0.000023)<0.05$, then Ho is rejected. Thus it can be concluded that simultaneously there is a significant influence between LTV, exchange rate, GDP, interest rate and ROE Against return. This simultaneous influence means the attachment of all independent variables has an important influence on the dependent variable.

Thus, investors should pay attention to the LTV factor, the macro economy represented by the exchange rate, GDP and the interest rate and the performance of the company described by ROE will affect the stock return of the company. This is needed by investors as a reference by investors in determining their investment strategy. Previous research has also seen the simultaneous effects of LTV, exchange rate, GDP, interest rate and ROE on stock returns made by (Salim \& Simatupang, 2016) and (Sudarno \& Pratiwi, 2014).

\section{Conclusion}

Research conducted on 5 companies in Property and Real Estate LQ45 listed on IDX during 2009-2017 period, by using multiple linear regression data panel data analysis, it can be concluded as follows:

Through t Test (Partial Test) to see the effect of LTV, exchange rate, GDP, interest rate and ROE partially to stock return proved as follows:

For the variable LTV (X1) obtained value of $\mathrm{t}$ arithmetic equal to 0.533506 . Because $t$ count $(-0.533506)>t$ table $(-1,974)$, then $\mathrm{HO}$ is accepted. Therefore, it can be concluded that LTV (X1) partially has no influence and significant return (Y). There has been no prior research on the impact of LTV on stock returns.

For the exchange rate variable (X2) obtained t value counted 1.251482. Because $t$ count $(1.251482)<t$ table $(1,974)$, then H0 is accepted. Therefore, it can be concluded that the exchange rate (X2) partially has no significant effect of return (Y). In line with the research of (Nasir \& Mirza, 2011), (Pratiwi \& Hendrawan, 2014).

For the variable of GDP (X3) obtained t value counted -4.179437. Because $t$ count $(-4.179437)>-t$ table $(-1,974)$, then $\mathrm{H} 0$ is rejected. Therefore, it can be concluded that GDP (X3) partially has a significant influence of return (Y). As with the research of (Aquasari, 2011).

For the variable interest rate (X4) obtained t value counted 1.373394. Because $t$ count $(-1.373394)<t$ table $(-1,974)$, then H0 is accepted. Therefore, it can be concluded that the interest rate (X4) partially has no significant effect of return (Y). In accordance with research (Aquasari, 2011), (Pratiwi \& Hendrawan, 2014) and (Anwar \& Farida, 2016).

For variable ROE (X5) obtained t value counted 1.997721. Because $t$ count $(1.997721)>t$ table $(1,974)$, then $\mathrm{H} 0$ is rejected. Therefore, it can be concluded that ROE (X5) partially has a significant influence of return $(\mathrm{Y})$. Agree with Farida's research (Anwar \& Farida, 2016).

Through F test (Simultaneous Test) to know the significance of an influence of independent variables simultaneously it is proved that simultaneously there is significant influence between LTV, exchange rate, GDP, interest rate and ROE to stock return. In line with (Prihantini, 2009), (Salim \& Simatupang, 2016) and (Sudarno \& Pratiwi, 2014).

\section{References}

[1] Ang, R. (1997). Buku Pintar Pasar Modal. Jakarta: Media Staff Indonesia.

[2] Anwar, M. K., \& Farida. (2016). Systematic Risk, Internal and External Factor To Stock Return Risiko Sistematis , Faktor Internal Dan Eksternal, 55-65.

[3] Aquasari, D. R. (2011). Analisis Faktor-Faktor Ekonomi Makro Yang Mempengaruhi Harga Saham Pada Industri Telekomunikasi Yang Tercatat Di Bursa Efek Indonesia. Universitas Gadjah Mada.

[4] Hadiansyah, N., \& Gunawan, B. (2017). Analisis Makro Ekonomi da Fundamental Terhadap Harga Saham Perbankan Yang Terdaftar Pada Index LQ45, 22(1), 26-36.

[5] Lukisto, J., \& Anastasia, N. (2014). Dampak Makroekonomi Terhadap Indeks Harga Saham Sektor Properti Di Indonesia Periode Tahun 1994-2012. Jurnal Analisa, 6(1), 9-21.

[6] Mankiw, Gregory, Quah, E., \& Wilson, P. (2014). Pengantar Ekonomi Makro (Asia). Jakarta: Salemba Empat.

[7] Maulida, A., Utami, E. S., \& Sumani. (2010). Pengaruh Kurs Dan Suku Bunga SBI Serta Inflasi Melalui Return On Asset Terhadap Return Saham. Keuangan.

[8] Nasir, A., \& Mirza, A. (2011). Pengaruh Nilai Kurs, Inflasi, Suku Bunga Deposito Dan Volume Perdagangan Saham Terhadap Return Saham Pada Perusahaan Perbankan Yang Terdaftar Di Bursa Efek Indonesia. Jurnal Ekonomi, Bisnis.

[9] Nasution, L. Z. (2013). Pengaruh Loan To Value Dan Shock Variabel Makro Ekonomi Terhadap Pertumbuhan Industri Properti.

[10] Pratiwi, E., \& Hendrawan, \& R. (2014). Pengaruh Indeks Harga Saham Gabungan, Faktor Ekonomi Makro dan Indeks Dow Jones Industrial Average terhadap Indeks Harga Saham LQ 45 Periode 2008-2012 dalam Keputusan Investasi. Jurnal Manajemen Indonesia, 14(1), 17-35.

[11] Salim, F. S., \& Simatupang, A. (2016). Kinerja Keuangan dan Kondisi Ekonomi Makro Terhadap Pengembalian Saham Perusahaan Property dan Real Estate yang Terdaftar di Bursa Efek Indonesia Periode Tahun 2011-2014, 4(1), 47-67.

[12] Setiawan, I. G. H., \& Mimba, N. P. S. H. (2015). Reaksi pasar pada regulasi loan to value. Akutansi, 1, 107-120.

[13] Sudarno, \& Pratiwi. (2014). Return on Equity Dan Total Asset Turnover Terhadap Return. STIE Pelita Indonesia, 23-38.

[14] Suharyanto, D., \& Asma, R. (2013). Analisis Abnormal Return Saham Sebelum Dan Sesudah Pengumuman Loan To Value KPR. Keuangan, 281-298.. 